\title{
Oceanological and Hydrobiological Studies
}

\author{
International Journal of Oceanograpby and Hydrobiology
}

Volume 41, Issue 3

ISSN 1730-413X

(54-63)

eISSN 1897-3191

2012

VERSITA

DOI: $10.2478 / \mathrm{s} 13545-012-0028-9$

Original research paper
Received:

Accepted:
May 06, 2011

February 16, 2012

\section{Diversity and distribution of cyanobacterial toxins in the Italian subalpine lacustrine district}

\author{
Leonardo Cerasino*, Nico Salmaso
}

Sustainable Agro-ecosystems and Bioresources Department, IASMA Research and Innovation Centre, Fondazione Edmund Mach, Via E. Mach, 1, I-38010 S. Michele all'Adige (TN), Italy

Key words: Cyanobacterial toxins, microcystins, anatoxin-a, LC-MS, subalpine lakes

\begin{abstract}
Nine lakes (Garda, Maggiore, Como, Iseo, Lugano, Idro, Pusiano, Ledro, and Levico) located in the Italian subalpine lacustrine district were chosen for a comparative study of the diversity and distribution of cyanobacterial toxins. All nine lakes are known to host different toxic cyanobacteria, mainly Planktothrix rubescens. An analytical protocol has been used, based on LC-MS technique, for determining 20 different toxins (14 microcystins, 2 nodularins, anatoxin-a and 3 cylindrospermopsins). In the investigation, microcystins were found in all lakes on all sampling dates. Anatoxin-a could be detected in 6 lakes, but it was only present in 4 lakes on all sampling dates (lakes Garda, Iseo, Como, and Maggiore). Nodularins and cylindrospermopsins were not detected at all. The number of microcystins detected in the survey was 9 , but 4 were the most abundant (dmRR, YR, dmLR, and LR); they were differently distributed among the lakes, thus providing each lake a unique toxic potential. Statistical analysis showed positive
\end{abstract}

*Corresponding Author e-mail: leonardo.cerasino@iasma.it correlations between total microcystin concentrations and eutrophication indicators and also between anatoxin-a concentrations and water temperature, suggesting that anthropic and climate-related stressors can have different impacts on the presence of different cyanotoxins.

\section{INTRODUCTION}

Cyanobacteria are photosynthetic prokaryotic organisms widely distributed in aquatic environments. In freshwater, they sometimes produce toxic blooms caused by several species belonging, among others, to the genera Microcystis, Planktothrix, and Anabaena (Whitton \& Potts 2000). Toxicity is linked to the production of specific secondary metabolites, which can be toxic to wildlife, domestic livestock, and humans. Microcystins, nodularins, cylindrospermopsins, anatoxins, and saxitoxins represent the most important classes of toxic compounds produced by cyanobacteria (AlShehri 2010, Aráoz et al. 2010, Botana 2000, Chorus \& Bartram 1999, Humpage 2008, Mazur et al. 2003, Namikoshi et al. 2003, Oksanen et al. 2004, Sivonen \& Jones 1999, Welker et al. 2006, Zurawell et al. 2005). All these toxins can pose serious risks to human health following exposure to high concentrations (acute intoxications), but microcystins are also particularly dangerous from a chronic point of view, since cumulative effects have been demonstrated in laboratory experiments. Moreover, some microcystins promote tumor growth (Falconer et al. 1996).

Since 1998 the World Health Organization (WHO 1998) has underlined the importance of monitoring microcystin concentration in water, and has recommended $1 \mu \mathrm{g} \mathrm{l}^{-1}$ as the limit in drinking water. This guideline has been derived from studies on the most toxic microcystin (LR) and refers to the total microcystin LR concentration (intra- plus extracellular) (Chorus \& Bartram 1999). This limit is also 
often used as reference when microcystin concentrations are measured using methods that are unable to distinguish among variants (ELISA tests); in this case it is assumed that only microcystin LR is present. This is a protective approach that, in the majority of cases, overestimates the risk. For a more accurate risk assessment a complete molecular profiling of the toxic compounds is required, but unfortunately this approach is laborious and costly. Several papers have been published about the occurrence of toxic cyanobacteria in Italian fresh water (Aktan et al. 2009, Barone et al. 2010, Bruno et al. 1994, Manganelli et al. 2010, Messineo et al. 2006, 2009, Naselli-Flores \& Barone 2007, Naselli-Flores et al. 2007, Salmaso et al. 2005, Sechi and Lugliè 1992, Viaggiu et al. 2004). These authors have shown that potentially toxic blooms can occur not only in eutrophic water basins but also in oligotrophic ones.

With these considerations in mind, we decided to undertake a comparative study in nine lakes located in the Italian subalpine district, which are very important both economically and environmentally. Our specific aim was to characterize the toxin profile of each lake at a molecular level, compare the different environments, and find possible correlations between toxins and environmental variables. We selected nine lakes of different characteristics: Garda, Maggiore, Como, Iseo, Lugano, Idro, Pusiano, Ledro, and Levico (Table 1). Five of them (Garda, Iseo, Como, Lugano, and Maggiore) are defined as deep subalpine lakes (DSL) and contain almost $80 \%$ of the total water. We decided to sample the lakes in summer and autumn, when cyanobacteria are most abundant, and to use LC-MS techniques for detecting cyanotoxins because these techniques are highly selective and sensitive (Bogialli et al. 2006, Dahlmann et al. 2003, Hiller et al. 2007, Spoof et al. 2007, Welker et al. 2006). The cyanotoxins we considered were cyclic peptides (microcystins and nodularins) and alkaloids (anatoxins and cylindrospermopsins) (Table 2).

\section{MATERIALS AND METHODS}

\section{Study site}

Table 1 reports the principal morphometric and hydrological characteristics of the lakes included in this research. All of the lakes are natural in origin, but the hydrology of lakes Idro and Ledro is strongly affected by the use of water for hydropower production. Following the classification of lake types summarised by the Water Framework Directive (EC Parliament and Council, 2000) and Buraschi et al. (2005), lakes Garda, Maggiore, Como, Iseo, Lugano, and Idro are classified as very deep and large. These five lakes underwent a significant increase in nutrients and trophic level from the 1960s to the 1990s, when remedial measures produced positive effects for lakes Maggiore, Como, and Lugano, but not for lakes Iseo and Garda (Mosello \& Giussani 1997; Salmaso et al. 2003, 2006, 2007; Salmaso \& Mosello 2010). Annual mean total phosphorus concentrations measured in the trophogenic layers $(0-20 \mathrm{~m})$ of the largest lakes were $10 \mu \mathrm{g} \mathrm{l}^{-1}$ (Garda, Maggiore), 15-30 $\mathrm{gg} \mathrm{l}^{-1}$ (Iseo, Como), and 15-40 $\mu \mathrm{g} \mathrm{l}^{-1}$ (Lugano). These observations classify lakes Maggiore and Garda as oligotrophic/oligo-mesotrophic, and lakes Como, Iseo, and Lugano as mesotrophic/eutrophic. Garibaldi et al. (1997) confirmed the mesotrophic level of Lake Idro, which showed epilimnetic total phosphorous concentrations ranging from 10 to $30 \mu \mathrm{g} \mathrm{l}^{-1}$. Lake Pusiano can be classified as eutrophic, with epilimnetic total phosphorous values ranging typically from 20 to $60 \mu \mathrm{g} \mathrm{l}^{-1}$ (Legnani et al. 2005). Lakes Ledro and Levico can be classified as mesotrophic (Flaim \& Pinamonti 2000).

\section{Sampling and environmental variables measurements}

Sampling occurred between June and October 2009. Sampling and field measurements were carried out in the central zone of the lakes at discrete depths. Six samplings were performed on Lake Garda, four on Lake Levico, two on lakes Maggiore, Como, Iseo, Lugano, and Pusiano, and only one on lakes Idro and Ledro. Temperature, $\mathrm{pH}$, and conductivity were measured in the field with portable instruments (WTW). Total phosphorus, nitric and ammonia nitrogen were measured in the laboratory following standard methods (APHA-AWWA-WPCF 1998).

For toxins extraction and analysis cyanobacteria biomass was obtained as follows: 2.51 of water were collected in amber glass bottles and filtered using 47 $\mathrm{mm}$ diameter GF-C filters. Filters were kept at $-20^{\circ} \mathrm{C}$ until toxins extraction and analysis.

\section{Reagents, standards, and equipment for $L C-M S$ analysis}

All organic solvents and reagents were LC-MS grade. Acetonitrile, methanol, formic acid, and 
Table 1

Main morphometric and hydrological characteristics of the southern subalpine lakes considered in this study. Data from IRSA (1984) and Ambrosetti \& Barbanti (1992; 1997).

\begin{tabular}{|c|c|c|c|c|c|c|c|c|c|c|}
\hline & & Garda & Iseo & Como & Lugano $^{a}$ & Maggiore & Levico & Ledro & Idro & Pusiano \\
\hline Latitude N & & $45^{\circ} 42^{\prime}$ & $45^{\circ} 44^{\prime}$ & $46^{\circ} 00^{\prime}$ & $45^{\circ} 58^{\prime}$ & $45^{\circ} 58^{\prime}$ & $46^{\circ} 00^{\prime} 51^{\prime \prime}$ & $45^{\circ} 52^{\prime} 39^{\prime \prime}$ & $45^{\circ} 46^{\prime}$ & $45^{\circ} 48^{\prime} 08^{\prime \prime}$ \\
\hline Longitude $\mathrm{E}$ & & $10^{\circ} 43^{\prime}$ & $10^{\circ} 04^{\prime}$ & $09^{\circ} 15^{\prime}$ & $08^{\circ} 59^{\prime}$ & $08^{\circ} 39^{\prime}$ & $11^{\circ} 16^{\prime} 41^{\prime \prime}$ & $10^{\circ} 45^{\prime} 04^{\prime \prime}$ & $10^{\circ} 32^{\prime}$ & $09^{\circ} 16^{\prime} 23^{\prime \prime}$ \\
\hline Altitude (m a.s.l.) & $\mathrm{h}$ & 65 & 186 & 198 & 271 & 193 & 440 & 655 & 368 & 259 \\
\hline Area $\left(\mathrm{km}^{2}\right)$ & A & 368 & 62 & 146 & 28 & 213 & 1.16 & 2.1 & 11.5 & 4.93 \\
\hline Maximum depth $(\mathrm{m})$ & $z_{\max }$ & 350 & 251 & 410 & 288 & 370 & 38 & 47 & 120 & 24 \\
\hline Mean depth $(m)$ & $\mathrm{z}_{\mathrm{m}}$ & 133 & 123 & 154 & 171 & 178 & 11.1 & 36 & 65 & 14 \\
\hline Watershed area $\left(\mathrm{km}^{2}\right)$ & $A_{w}$ & 2290 & 1842 & 4508 & 297 & 6599 & 27 & 101 & 609 & 94 \\
\hline Mean outflow discharge $\left(\mathrm{m}^{3} \mathrm{~s}^{-1}\right)$ & & 58.4 & 58.7 & 158.0 & 12.0 & 291.3 & 0.43 & 2.83 & 22.1 & 3.22 \\
\hline Renewal time (years) & $\tau$ & 26.6 & 4.1 & 4.5 & 12.4 & 4.1 & 1.0 & 0.9 & 1.2 & 0.7 \\
\hline
\end{tabular}

- Northern basin

Table 2

Cyanotoxins data and MS/MS detection parameters. "dm" is desmethylated; TEF is the "Toxicity Equivalent Factor"; transitions 1 and 2 represent the mass transitions monitored during the MRM MS/MS experiments; DP is declustering potential; CE is collision energy. Toxicity data are taken from van Apeldoorn et al. (2007) and Sivonen and Jones (1999) and refer to intraperitoneal $\mathrm{LD}_{50}$ in mice.

\begin{tabular}{|c|c|c|c|c|c|c|c|}
\hline & \multirow{2}{*}{ Toxicity ( $\mu \mathrm{g} \mathrm{kg}^{-1}$ b.w.) } & \multirow{2}{*}{ TEF } & \multirow{2}{*}{ Molecular weight (Da) } & \multicolumn{4}{|c|}{ MS/MS parameters } \\
\hline & & & & Transition 1 & Transition 2 & $\mathrm{DP}(\mathrm{V})$ & CE (V) \\
\hline \multicolumn{8}{|l|}{ Microcystins } \\
\hline RR & $500-800$ & 0.0769 & 1038 & $520 / 135$ & $520 / 213$ & 100 & 43 \\
\hline $\mathrm{dmRR}$ & $180-250$ & 0.2325 & 1024 & $513 / 135$ & $513 / 213$ & 100 & 43 \\
\hline YR & $150-200$ & 0.2857 & 1045 & $523 / 135$ & $523 / 213$ & 50 & 20 \\
\hline$d m Y R$ & n.a. ${ }^{a}$ & & 1031 & $516 / 135$ & $516 / 213$ & 50 & 20 \\
\hline LR & 50 & 1 & 995 & $498 / 135$ & $498 / 213$ & 50 & 20 \\
\hline $\mathrm{dm} L \mathrm{R}$ & $50-250$ & 0.3333 & 981 & $491 / 135$ & $491 / 213$ & 50 & 20 \\
\hline LA & 50 & 1 & 910 & $911 / 135$ & $911 / 213$ & 70 & 80 \\
\hline $\mathrm{dmLA}$ & n.a. & & 896 & $897 / 135$ & $897 / 213$ & 70 & 80 \\
\hline$L Y$ & 90 & 0.5556 & 1002 & $1003 / 135$ & $1003 / 213$ & 90 & 100 \\
\hline $\mathrm{dmLY}$ & n.a. & & 988 & $989 / 135$ & $989 / 213$ & 90 & 100 \\
\hline LW & n.a. & & 1025 & $1026 / 135$ & $1026 / 213$ & 90 & 90 \\
\hline$d m L W$ & n.a. & & 1011 & $1012 / 135$ & $1012 / 213$ & 90 & 90 \\
\hline $\mathrm{LF}$ & n.a. & & 986 & $987 / 135$ & $987 / 213$ & 90 & 100 \\
\hline $\mathrm{dmLF}$ & n.a. & & 972 & $973 / 135$ & $973 / 213$ & 90 & 100 \\
\hline Nodularin- $\mathrm{R}$ & $30-50$ & 0.8000 & 825 & $826 / 70$ & $826 / 135$ & 90 & 100 \\
\hline dmNodularin- $\mathrm{R}$ & n.a. & & 811 & $812 / 70$ & $812 / 135$ & 90 & 100 \\
\hline Anatoxin-a & 375 & & 165 & $166 / 149$ & $166 / 91$ & 70 & 30 \\
\hline Cylindrospermopsin & 170 & & 415 & $416 / 194$ & $416 / 176$ & 90 & 53 \\
\hline 7-epi-Cylindrospermopsin & n.a. & & 415 & $416 / 194$ & $416 / 176$ & 90 & 53 \\
\hline Desoxy-Cylindrospermopsin & n.a. & & 399 & $400 / 194$ & $400 / 176$ & 90 & 30 \\
\hline Phenylalanine $^{b}$ & & & 165 & $166 / 120$ & & 70 & 30 \\
\hline
\end{tabular}

ammonium formate were purchased from SigmaAldrich. Microcystins (LA, LW, LY, LR, RR, LF, and YR), nodularin-R, and cylindrospermopsin standards were purchased from Vinci Biochem; anatoxin-a was purchased from Tocris Cookson Ltd.
The LC system consisted of a Waters Acquity UPLC $^{\circledR}$ equipped with a binary solvent manager, a sample manager carrying a $10 \mu \mathrm{l}$ injection loop. The LC apparatus was directly coupled to an $A B$ Sciex 4000 QTRAP hybrid triple quadrupole-linear ion trap 
mass spectrometer equipped with a Turbo Ion Spray interface. High purity nitrogen was employed as nebulizer, auxiliary, curtain, and collision gas. All instruments were controlled and data collected using Applied Biosystems Analyst 1.5 software.

\section{Cyanotoxins extraction and LC-MS analysis}

Toxins extraction from cyanobacteria biomass was performed according to established procedures (Meriluoto \& Codd 2005, Rohrlack et al. 2003) with minor modifications; each filter was put in a borosilicate glass centrifuge tube and $6 \mathrm{ml}$ of extraction solvent (50\% methanol containing $0.1 \%$ formic acid) were added. The tube content was first homogenized and then sonicated for 5 minutes. The sample was then centrifuged at $4000 \mathrm{~g}$ for 10 minutes. The supernatant was transferred in a borosilicate glass tube. The extraction was repeated twice and the three supernatants were put together. A $2 \mathrm{ml}$ aliquot was taken, filtered through a $0.2 \mu \mathrm{m}$ nylon syringe filter, transferred in a borosilicate glass vial, and quickly analyzed by LC-MS/MS.

The analysis of microcystins (Fig. 1) and nodularin was carried out using a Waters Acquity BEH C18 (1.7 $\mu \mathrm{m}$ particle size, $2.1 \times 50 \mathrm{~mm})$ column kept at $40^{\circ} \mathrm{C}$. The injection volume was $7 \mu \mathrm{l}$. A linear gradient of mobile phases $\mathrm{A}$ and $\mathrm{B}$ was employed ( $t$ in minutes): $t_{0} 70 \% \mathrm{~A}, t_{5} 20 \% \mathrm{~A}, t_{6} 70 \%$ $\mathrm{A}, t_{7} 70 \% \mathrm{~A} ; \mathrm{A}$ and $\mathrm{B}$ were water and acetonitrile, respectively, both containing $0.1 \%$ formic acid (Rohrlack et al. 2008). The total run time was 7 minutes and the flow rate $0.25 \mathrm{ml} \mathrm{min}{ }^{-1}$.

The analysis of anatoxin-a and cylindrospermopsins (Fig. 1) was carried out using a Waters Acquity HILIC $(1.7 \mu \mathrm{m}$ particle size, $2.1 \times 50$ $\mathrm{mm}$ ) column kept at $30^{\circ} \mathrm{C}$. The injection volume was $7 \mu \mathrm{l}$ and the linear gradient scheme was: $t_{0} 80 \% \mathrm{~A}, t_{5}$ $20 \% \mathrm{~A}, t_{6}=80 \% \mathrm{~A}, t_{7}=80 \% \mathrm{~A} ; \mathrm{A}$ and $\mathrm{B}$ were 0.05 $\mathrm{M}$ ammonium formate in water and pure methanol, respectively (Dell'Aversano et al. 2004). The total run time was 7 minutes and the flow rate $0.25 \mathrm{ml} \mathrm{min}^{-1}$. In both cases the mass detector was operated in positive Electro Spray mode (ESI+) using the Multiple Reaction Monitoring (MRM) scanning mode. General settings were as follows: ion spray voltage $5000 \mathrm{~V}$, entrance potential $10 \mathrm{~V}$, cell exit potential $10 \mathrm{~V}$, interface heater temperature $300^{\circ} \mathrm{C}$. Compound-specific settings of the mass detector are listed in table 1. As reported in the same table, the number of microcystins monitored included the seven standard microcystins plus the respective seven

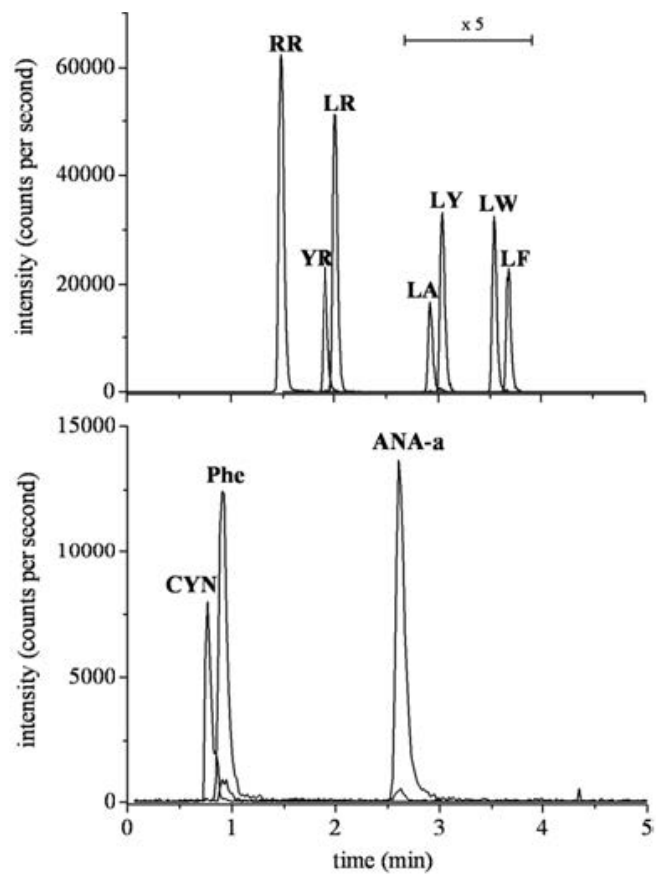

Fig. 1. LC-MS/MS chromatograms of standard cyanotoxins: microcystins (top chromatogram); alkaloids (anatoxin-a, cylindrospermopsin) + phenylalanine (bottom chromatogram).

desmethyl variants.

Quantitation was performed with the external standard procedure. Two multistandard solutions (one for microcystins/nodularin and one for anatoxin-a and cylindrospermopsin) were prepared at 5 levels of concentration (in the range $0.1-100$ $\left.\mu \mathrm{g} \mathrm{l}^{-1}\right)$. For the quantification of desmethylmicrocystins, the calibration curves of the parent microcystins were employed. Linearity of response was obtained over a 4-fold concentration range (0.1 $\left.100 \mu \mathrm{g} \mathrm{l}^{-1}\right)$. The limits of quantitation for microcystins were (ng $\mathrm{l}^{-1}$ ): 0.1 for RR and LR, 0.5 for YR, 1.0 for LA and LY, and 2.0 for LW and LF. Nodularin-R

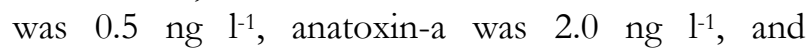
cylindrospermopsin was $3.0 \mathrm{ng} \mathrm{l}^{-1}$.

\section{RTP calculation}

Relative Toxic Potential (RTP) for each lake was calculated as the sum of the relative abundance of each microcystin multiplied by the corresponding "toxicity equivalent factor" (Wolf et al. 2002) (TEF, Table 2). RTP is expressed as a number between 0 and 1 and is a measure of the toxic potential of a lake. RTP is a useful tool for comparing lakes that have different microcystin distributions. 


\section{Data analysis}

Correlations between environmental, physiographic, and biotic variables were computed

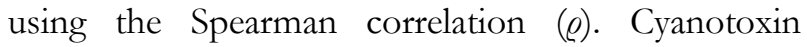
samples were ordered by Correspondence Analysis (CA) (Legendre \& Legendre 1998). The identification of groups of samples sharing similar cyanotoxin composition was carried out by applying a cluster analysis (average linkage method) to a dissimilarity matrix obtained using euclidean distances after scaling the site vectors to length 1 (chord distance). This distance coefficient is not influenced by the presence of many zeros in the data matrices (as in our case). The groups were separated considering constant distances on the cluster tree. Before CA and cluster computation, the data were square root transformed to reduce the weight of the more abundant cyanotoxins. Statistical analyses were carried out with $\mathrm{R}$ software (R Development Core Team 2011). For these calculations, the cyanotoxin concentrations reported in table 3 were used; when concentrations were undetectable, a 0 value was used.

\section{RESUlts}

\section{Toxin diversity and distribution}

In the survey we identified nine different microcystins, with four being the most common (Table 4). The most common microcystin was $\mathrm{dmRR}$, dominant in 8 out of 9 lakes and representing more than $90 \%$ of the total in lakes Garda, Ledro, and Idro. The microcystin YR was dominant in Lake Levico $(60 \%)$ and was also particularly abundant in Lake Iseo (25\%). The microcystin dmLR was the second most abundant microcystin in Lake Levico (27\%). Microcystin LR was important only in Lake Maggiore (37\%).

In order to compare the different lakes in terms of risks posed by microcystins, we have calculated a "Relative Toxic Potential" (RTP, Table 4) for each lake, which takes into account both the microcystin diversity and the relative toxicity (toxicity equivalent factor, Table 2). Looking at RTP values of the investigated lakes, Lake Maggiore clearly has the highest (0.52), since $37 \%$ of its total microcystin content is due to the very toxic LR; all the other lakes

Table 3

Intracellular concentrations of cyanotoxins and main physical and chemical variables in the trophogenic layer (0-20 $\mathrm{m}$ mean values). $M C_{\text {tot }}$ indicates the total microcystin content; $M C_{\text {totLR }}$ indicates the total microcystin content expressed as LR equivalents; Temp indicates temperature; Cond indicates conductivity at $20^{\circ} \mathrm{C}$; DIN indicates dissolved inorganic nitrogen; TP indicates total phosphorus.

\begin{tabular}{|c|c|c|c|c|c|c|c|c|c|c|}
\hline \multirow{2}{*}{ Lake } & \multirow{2}{*}{ Sampling date } & \multirow{2}{*}{ Codsample } & \multicolumn{3}{|c|}{ Cyanotoxins concentrations $\left(\mathrm{ng} \mathrm{I}^{-1}\right.$ ) } & \multicolumn{5}{|c|}{ Physical and chemical variables } \\
\hline & & & $\mathrm{MC}_{\text {tot }}$ & $\mathrm{MC}_{\text {totLR }}$ & anatoxin-a & Temp. $\left({ }^{\circ} \mathrm{C}\right)$ & $\mathrm{pH}$ & Cond. $\left(\mu \mathrm{S} \mathrm{cm}^{-1}\right)$ & $\operatorname{DIN}\left(\mu \mathrm{g} \mathrm{N}^{-1}\right)$ & $\mathrm{TP}\left(\mu \mathrm{g} \mathrm{P} \mathrm{^{-1 } )}\right.$ \\
\hline \multirow{6}{*}{ Garda } & 03/06/09 & gar6a & 0.3 & 0.08 & 45 & 16.3 & 8.35 & 224 & 305 & 10 \\
\hline & $30 / 06 / 09$ & gar6b & 3 & 1 & 66 & 18.2 & 8.69 & 215 & 270 & 12 \\
\hline & $29 / 07 / 09$ & gar7 & 27 & 7 & 591 & 20.2 & 8.47 & 207 & 177 & 11 \\
\hline & $25 / 08 / 09$ & gar8 & 63 & 16 & 366 & 21.5 & 8.35 & 205 & 154 & 9 \\
\hline & $22 / 09 / 09$ & gar9 & 95 & 24 & 230 & 19.9 & 8.28 & 205 & 168 & 8 \\
\hline & 20/10/09 & gar10 & 95 & 24 & 380 & 17.2 & 8.29 & 209 & 180 & 8 \\
\hline & & & & & & & & & & \\
\hline \multirow{2}{*}{ Iseo } & $29 / 06 / 09$ & ise6 & 90 & 23 & 410 & 16.8 & 8.40 & 231 & 741 & 14 \\
\hline & $06 / 10 / 09$ & ise10 & 112 & 29 & 68 & 17.0 & 8.13 & 233 & 645 & 12 \\
\hline & & & & & & & & & & \\
\hline \multirow{2}{*}{ Como } & $21 / 07 / 09$ & com7 & 201 & 61 & 440 & 21.0 & 8.38 & 169 & 811 & 17 \\
\hline & $07 / 09 / 09$ & com9 & 80 & 24 & 103 & 20.2 & 8.32 & 163 & 507 & 14 \\
\hline & & & & & & & & & & \\
\hline \multirow{2}{*}{ Lugano } & $14 / 07 / 09$ & lug7 & 84 & 24 & n.d. ${ }^{a}$ & 17.3 & 8.27 & 205 & 169 & 17 \\
\hline & 08/09/09 & lug9 & 98 & 28 & n.d. & 16.9 & 8.18 & 198 & 240 & 12 \\
\hline & & & & & & & & & & \\
\hline \multirow{2}{*}{ Maggiore } & $22 / 07 / 09$ & mag7 & 26 & 14 & 123 & 18.0 & 7.73 & 124 & 765 & 11 \\
\hline & 07/10/09 & mag10 & 76 & 40 & 125 & 16.4 & 7.93 & 134 & 629 & 11 \\
\hline & & & & & & & & & & \\
\hline \multirow{4}{*}{ Levico } & $16 / 06 / 09$ & lev6 & 16 & 5 & n.d. & 13.0 & 8.19 & 266 & 823 & 14 \\
\hline & $18 / 08 / 09$ & lev8 & 115 & 34 & n.d. & 14.9 & 8.08 & 273 & 584 & 15 \\
\hline & $15 / 09 / 09$ & lev9 & 225 & 67 & n.d. & 14.0 & 8.10 & 265 & 656 & 18 \\
\hline & $14 / 10 / 09$ & lev10 & 278 & 83 & 17 & 14.0 & 8.10 & 256 & 394 & 15 \\
\hline Ledro & $12 / 10 / 09$ & led10 & 4596 & 1065 & 3 & 11.5 & 8.14 & 269 & 651 & 14 \\
\hline & & & & & & & & & & \\
\hline Idro & $01 / 07 / 09$ & idr7 & 15 & 5 & n.d. & 15.6 & 8.35 & 199 & 662 & 15 \\
\hline \multirow{3}{*}{ Pusiano } & & & & & & & & & & \\
\hline & $15 / 07 / 09$ & pus7 & 525 & 132 & n.d. & 17.9 & 7.91 & 276 & 748 & 56 \\
\hline & 19/10/09 & pus10 & 3458 & 869 & n.d. & 14.7 & 7.91 & 273 & 595 & 68 \\
\hline
\end{tabular}


Table 4

Mean relative abundances of individual microcystins and RTP (Relative Toxic Potential) values in the investigated lakes. The four major microcystin variants are shown.

\begin{tabular}{|c|c|c|c|c|c|c|}
\hline \multirow{2}{*}{ Lake } & \multicolumn{5}{|c|}{ microcystin variants \% } & \multirow{2}{*}{ RTP } \\
\hline & $\mathrm{dmRR}$ & YR & dmLR & LR & Sum $^{a}$ & \\
\hline Garda & 92 & 3 & 3 & 2 & 100 & 0.25 \\
\hline Iseo & 64 & 25 & 8 & 1 & 98 & 0.26 \\
\hline Como & 77 & 8 & 4 & 9 & 98 & 0.31 \\
\hline Lugano & 75 & 1 & 10 & 8 & 94 & 0.29 \\
\hline Maggiore & 47 & 8 & 6 & 37 & 98 & 0.52 \\
\hline Levico & 12 & 60 & 27 & 1 & 100 & 0.30 \\
\hline Ledro & 97 & 1 & 1 & 0 & 99 & 0.23 \\
\hline Idro & 95 & 0 & 5 & 0 & 100 & 0.24 \\
\hline Pusiano & 77 & 16 & 5 & 1 & 99 & 0.25 \\
\hline
\end{tabular}

have lower RTP values that fall in a narrow range between 0.23 and 0.31 .

Moving into the quantitative aspect of the microcystin content, table 3 reports the total microcystin concentrations $\left(\mathrm{MC}_{\mathrm{tot}}\right)$, calculated as the sum of the contributions of each variant. Globally, concentrations range from less than $1 \mathrm{ng} \mathrm{l}^{-1}$ to about $4600 \mathrm{ng} \mathrm{l}^{-1}$. Lakes Pusiano and Ledro had the highest concentrations (3458 and $4596 \mathrm{ng} \mathrm{l}^{-1}$, respectively), while lakes Idro and Garda had the lowest. Generally speaking, $\mathrm{MC}_{\mathrm{tot}}$ values were higher for late summer and autumn sampling dates. Lake Como was the only exception to this general trend. Table 3 shows the total microcystin concentrations expressed as LR equivalents $\left(\mathrm{MC}_{\text {totLR }}\right.$ column); those values were obtained from the $\mathrm{MC}_{\text {tot }}$ values multiplied by the corresponding RTP values. MCtot $\mathrm{LR}_{\mathrm{R}}$ reflects the real risks associated with the presence of microcystins in the water better than $\mathrm{MC}_{\text {tot }}$ because it takes into account the different toxicities of the variants. In the lakes in this study, $\mathrm{MC}_{\text {totLR }}$ values are on average three times lower than $\mathrm{MC}_{\text {tot }}$ values.

As far as other toxins are concerned, anatoxin-a was consistently detected in 4 lakes (Garda, Iseo, Como and Maggiore), at concentrations ranging from 45 to about $590 \mathrm{ng} \mathrm{l}^{-1}$ (Table 3). The highest value was found in Lake Garda in July. One sample from Lake Levico and one sample from Lake Ledro also contained traces of this toxin (17 and $3 \mathrm{ng} \mathrm{l}^{-1}$ respectively). Neither nodularins nor cylindrospermopsins were detectable in the lakes.

\section{Data analysis and relationship between cyanotoxins and environmental variables}

The ordination of samples and cyanotoxins obtained through Correspondence Analysis are reported in Figure 2a. The eigenvalues associated with the first two CA axes were 0.41 and 0.16 , with explained proportions of $50 \%$ and $20 \%$, respectively. The results clearly indicated the existence of clusters of different lakes more strongly associated with diverse cyanotoxins. Cluster analysis aided in the identification of these groups (Fig. 2b). The most striking differences in the ordination plot include the associations of samples belonging to lakes Garda,

a)

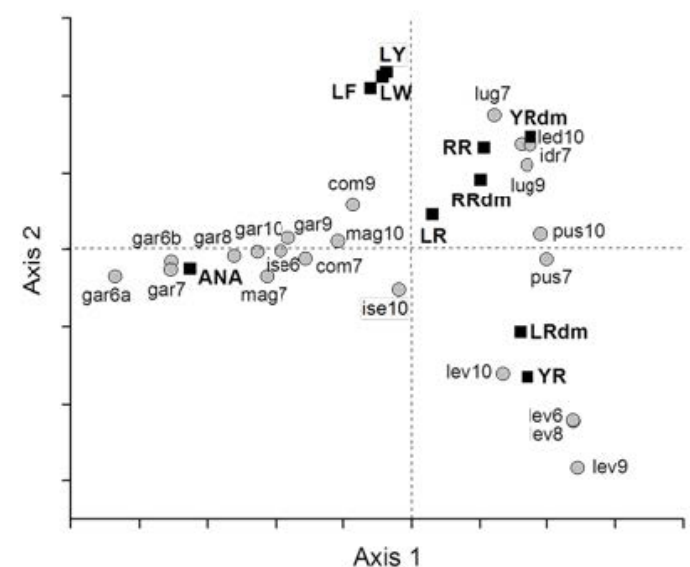

b)

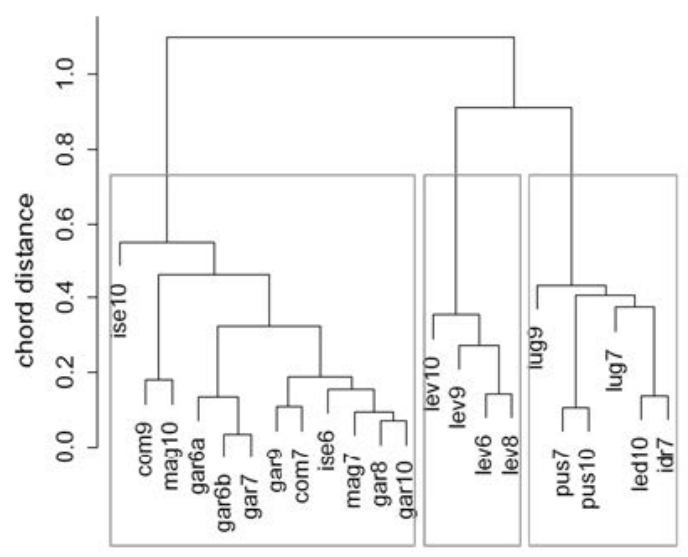

Fig. 2. a) ordination of lakes and cyanotoxins in the correspondence analysis plane defined by the first two axes; b) cluster analyses of water samples. Lakes are coded with a three letter codon (gar, Garda; ise, Iseo; com, Como; lug, Lugano; mag, Maggiore; lev, Levico; led, Ledro; idr, Idro; pus, Pusiano) followed by the month number. ANA is Anatoxin-a; Microcystins have been coded as in Table 2 . 
Como, Maggiore, and Iseo (almost all in the left quadrants), Levico (lower-right quadrant), and Lugano, Pusiano, Ledro, and Idro (upper-right quadrant). These three groups of lakes showed a greater association with anatoxin-a, microcystins YR and $\mathrm{dmLR}$, and with the remaining microcystins (excluding LR), respectively. It is interesting to observe that samples belonging to the same lakes were consistently grouped in the same clusters. A partial exception was represented by the autumnal samples of lakes Maggiore and Iseo (October), and Como (September), which grouped at a higher level of distance compared with the other samples (see also Fig. 2a). Nevertheless, the results appear to indicate a lower degree of seasonal variability in cyanotoxin composition in the single lakes as compared with the remaining lakes.

Total microcystin concentrations showed a positive correlation with TP $(\varrho=0.54 ; p<0.05)$ and conductivity $(\varrho=0.50 ; \quad p<0.05)$, and a negative correlation with $\mathrm{pH} \quad(\varrho=-0.51 ; p<0.05)$. Similar relationships, but with the opposite sign, were found for anatoxin-a, which was negatively correlated with TP $(\varrho=-0.61, p<0.01)$ and conductivity $(\varrho=-0.47$, $p<0.05)$, and positively correlated with $\mathrm{pH}(\varrho=0.50$, $p<0.05)$. Moreover, unlike the microcystins, anatoxin-a showed a strong link with water temperatures $(\varrho=0.63, p<0.01)$ and SRP $(\varrho=-0.62$, $p<0.01)$. It is interesting to observe that, consistent with the positive link with water temperature, mean lake concentrations of anatoxin-a showed a negative relationship with lake altitude $(\varrho=-0.68, p<0.05, n=9)$. In addition, differences between the two cyanotoxin types were highlighted by their opposite - even if at the border of significance for many of them relationships with lake dimensions and watershed areas: anatoxin-a vs $\mathrm{A}, \mathrm{V}$, and $\mathrm{A}_{\mathrm{w}}$ : $\varrho=0.66(p<0.1)$, 0.70 ( $p<0.05), 0.63(p<0.1)$; microcystins $v$ s $\mathrm{A}, \mathrm{V}$, and $\mathrm{A}_{\mathrm{w}}: \varrho=-0.63,-0.62,-0.58(p<0.1)$.

\section{DISCUSSION}

\section{$L C-M S$ analysis}

One main limitation of the chemical methods for the detection of microcystins is the limited availability of analytical standards (only 7 out of more than 70 existing variants are available). However, we took advantage of mass spectrometry specificity to extend the panel of monitored molecules to molecules for which no commercial standards were available, but which were strictly related chemically to commercially available ones; we could therefore confidently identify and quantify seven additional desmethyl-microcystins and one desmethyl-nodularin (Table 2). This approach turned out to be critical because it allowed us to determine that a desmethyl variant (dmRR) was actually the most abundant microcystin in the investigated lakes and that other desmethyl variants (dmLR and dmYR) were also present.

Besides specificity, the mass spectrometric detection method also showed high sensitivity; it allowed us to detect toxins in very low quantities (ng $1^{-1}$ ) without the need for pre-concentration procedures.

\section{Toxin diversity and distribution}

Based on microcystin diversity, the investigated lakes could be classified in two different groups: a group of 3 lakes (Garda, Ledro, and Idro) in which microcystin dmRR represented more than $90 \%$ of the total; and a second group of 4 lakes (Iseo, Como, Lugano, and Pusiano) in which dmRR was between $64 \%$ and $77 \%$, and in which other microcystins (either YR, or dmRR, or LR) had greater importance. The remaining two lakes (Maggiore and Levico) had peculiar microcystin distributions. Compared to the groups mentioned above, Lake Maggiore had a lower percentage of microcystin dmRR (47\%) and a notably higher percentage of microcystin LR (37\%). Lake Levico had, instead, an even lower percentage of microcystin dmRR $(13 \%)$ and a higher percentage of microcystin YR $(60 \%)$.

By determining the composition of the microcystin populations, we could classify the nine lakes based on their "relative toxic potential" (RTP of Table 4). Lakes with higher RTP have more toxic microcystins, and therefore have the potential of hosting more dangerous episodes compared to lakes with lower RTP. The RTP values of the lakes included in the two groups defined above plus Lake Levico were very similar (the average value was 0.27 ), thus indicating that these lakes had almost the same toxic potential. Lake Maggiore, on the other hand, had an RTP value almost twice as high (0.52), thus indicating that the cyanobacteria population in this lake was much more toxic than the other lakes.

Considering the total absolute content of microcystins $\left(\mathrm{MC}_{\mathrm{tot}}\right)$, there was a clear relationship with trophic status: the highest concentrations were found in the most eutrophic lake (Pusiano) and in a mesotrophic lake (Ledro). Concentrations were 
always below $0.1 \mu \mathrm{g}^{-1}$ in the two more oligotrophic lakes (Maggiore and Garda).

As mentioned earlier, for a more accurate risk assessment, $\mathrm{MC}_{\text {totLR }}$ values instead of $\mathrm{MC}_{\text {tot }}$ values have to be considered. In this regard, looking at table $3, \mathrm{MC}_{\text {totLR }}$ were always well below the $1 \mu \mathrm{g} \mathrm{l}^{-1}$ limit recommended by WHO for drinking water, with only one exception: the sample from Lake Ledro, which slightly exceeded that limit $\left(1.065 \mu \mathrm{g} \mathrm{l}^{-1}\right)$. It is worthwhile to point out that the WHO limit refers to the total toxin content (intracellular plus extracellular), while our data refer only to the intracellular content. However, considering that at least $90 \%$ of the total microcystin content is intracellular (Codd 1995, Meriluoto \& Codd 2005, van Apeldoorn et al. 2007, Kosol et al. 2009), our data can be assumed to be a rough estimation of the total content.

The presence of microcystins is linked to the presence of toxic cyanobacteria. All nine lakes considered here are known to host populations of Planktothrix rubescens, which is one of the major producers of microcystins. In particular, lakes Pusiano and Ledro are known to produce huge blooms of this cyanobacterium (e.g., Flaim \& Pinamonti 2000, Legnani et al. 2005). Another important microcystin producer, especially in the deeper and larger lakes, is Microcystis aeruginosa. In recent years, this species caused many blooms in the meso- and eutrophic lakes (Iseo, Como, and Lugano; Mosello et al. 2010). The most characteristic species, however, even in these large lakes, is $P$. rubescens.

Although microcystins are primarily considered in monitoring the water quality, other toxins may be responsible for severe acute poisoning episodes (neurotoxins). In this study we have demonstrated that neurotoxins are also present in some lakes. Specifically, anatoxin-a has been found almost exclusively in the largest water bodies. This could be in line with the progressive invasion of populations of Dolichospermum (Anabaena) lemmermannii that has been documented in recent years in the deep southern subalpine lakes (Salmaso 2005, Mosello et al. 2010). Colonies of this species have a regular development during the year, being present in almost undetectable levels from late autumn to late spring, and reaching noticeable densities in summer and early-mid autumn (Salmaso 2010). Generally, the colonies of $D$. lemmermannii are present in low quantities in the trophogenic layers, reaching very high densities only when forming surface scums (Salmaso 2005).

\section{Relationship between cyanotoxins and environmental variables}

As far as the relationship between cyanotoxins and environmental variables is concerned, a clear positive relationship between cyanotoxin concentrations and lake trophic status was observed only for total microcystins. Instead, anatoxin-a showed a strong and positive link with water temperature. The strong link between anatoxin-a and water temperature could be explained by the seasonality of $D$. lemmermannii. In addition, the higher quantity of anatoxin-a in lakes at lower altitudes could be explained by the higher temperatures that characterise these water bodies compared with those at higher altitudes. Consequently, we can argue that the apparent morphometric factor (anatoxin-a is preferably present in the largest lakes) is a consequence of the location of the largest and deeper water bodies at lower altitudes. In our database, besides a positive correlation with water temperature, lake surfaces and volumes show a strong and negative relationship with lake altitude $(\varrho=-0.88$ and $0.82 ; p<0.01)$.

\section{CONCLUSIONS}

This research represents the first comprehensive account of the distribution of cyanobacterial toxins in Northern Italy's lake district. By employing accurate LC/MS techniques, the analyses demonstrated the widespread presence of a large number of microcystins, a localized presence of anatoxin-a in the largest low altitude lakes, and no detectable levels of nodularins and cylindrospermopsins. The concentrations of cyanotoxins found in the pelagic and epilimnetic zones of the studied lakes did not reach very high concentrations, especially if compared with other studies investigating cyanotoxin accumulation in algal scums or in lakes with higher trophic status. The largest concentrations of microcystins were documented in eutrophic and mesotrophic lakes. As for microcystins, which were present with many different compounds, it is worth noting that the majority belonged to variants less toxic than LR, which WHO uses as a reference. This must be taken into account when evaluating the potential toxic impact of microcystins on water use.

In this paper we have introduced a way of classifying lakes based on their RTP (relative toxic potential); this tool facilitates comparisons of relative 
toxicity between different toxic populations.

The two classes of cyanotoxins (microcystins and anatoxin-a) responded differently to environmental drivers linked to eutrophication and climatic factors. Microcystins were positively related to the trophic status of the lakes. Conversely, anatoxin-a showed a strong relationship with water temperatures, and an apparent negative relationship with trophic status. These results suggest an uncoupling of the two trophic and climatic drivers in the control of the distribution of microcystins and anatoxin-a in lakes of different climatic location and physiographic characteristics.

\section{ACKNOWLEDGEMENTS}

Many colleagues are kindly acknowledged for logistic support in the field and for critical discussions: Marco Simona (Scuola Universitaria Professionale della Svizzera Italiana, Switzerland), Fabio Buzzi (Environmental Protection Agency, Lombardia), Letizia Garibaldi (University of MilanoBicocca, Milan). We are grateful to Mario Contesini (Institute of Ecosystem Study, Verbania-Pallanza), the Fire Department of the Autonomous Province of Trento, Nicola Merlo and Andrea Zampedri (IASMA Research and Innovation Centre, San Michele all'Adige) for their support in field operations.

\section{REFERENCES}

Aktan Y., Lugliè A., Sechi N., 2009, Morphological plasticity of dominant species in response to nutrients dynamics in Bidighinzu Reservoir of Sardinia, Italy, Turk. J. Fish Aq. Sci., 9:137-144.

Al-Shehri A.M., 2010, Toxin-producing blooms of the cyanobacterium Microcystis aeruginosa in rainwater ponds in Saudi Arabia, Oceanol. Hydrobiol. St., 34, 4, 173-189

Ambrosetti W., Barbanti L., 1992, Physical limnology in Italy: an bistorical review, Memorie Istituto Italiano Idrobiologia, 50:3759.

Ambrosetti W. and Barbanti L., 1997, Alcune problematiche fisiche dei grandi laghi sudalpini, Documenta Istituto Italiano Idrobiologia, 61:3-18 (in Italian).

APHA-AWWA-WPCF, 1998, Standard methods for the Examination of Water and Wastewater, 20 ${ }^{\text {th }}$ Edition, APHA-AWWA-WPCF (Eds.), Washington.

Aráoz R., Molgó J., de Marsac N.T., 2010, Neurotoxic cyanobacterial toxins, Toxicon, 56, 5: 813-828.

Barone R., Castelli G., Naselli-Flores L., 2010, Red sky at night cyanobacteria delight: the role of climate in structuring phytoplankton assemblage in a shallow, Mediterranean lake (Biviere di Gela, southeastern Sicily), Hydrobiologia, 639:43-53.

Bogialli S., Bruno M., Curini R., Di Corcia A., Fanali C., Laganà A., 2006, Monitoring algal toxins in lake water by liquid chromatography tandem mass spectrometry, Environ. Sci. Technol., 40:2917-2923.

Botana L.M. Ed, 2000, Seafood and freshwater toxins, Pharmacology, physiology and detection, Marcel Dekker, Inc, New York, p 798.

Bruno M., Barbini D.A., Pierdominici E., Serpe A.P., Ioppolo A., 1994. Anatoxin-a and a previously unknown toxin in Anabaenaplanktonica from blooms found in lake Mulargia (Italy), Toxicon, 32, 3:369-373.

Buraschi E., Salerno F., Monguzzi C., Barbiero G., Tartari G., 2005, Characterization of the Italian lake-types and identification of their reference sites using anthropogenic pressure factors, J. Limnol., 64:75-84.

Chorus I. and Bartram J. Eds., 1999, Toxic cyanobacteria in water: a guide to their public health consequences, monitoring and management, E \& FN Spon, London.

Codd G.A., 1995, Cyanobacterial toxins: occurrence, properties and biological significance, Water Sci. Technol., 32:149-156.

Dahlmann J., Budakowski W.R., Luckas B., 2003, Liquid chromatography-electrospray ionisation-mass spectrometry based method for the simultaneous determination of algal and cyanobacterial toxins in phytoplankton from marine waters and lakes followed by tentative structural elucidation of microcystins, J. Chromatogr. A, 994:45-57.

Dell'Aversano C., Eaglesham G., Quilliam M.A., 2004, Analysis of cyanobacterial toxins by bydrophilic interaction liquid chromatographymass spectrometry, J. Chromatogr. A, 1028:155-164.

EC Parliament and Council, 2000, Directive 2000/60/EC of the European Parliament and of the Council of 23 October 2000. Establishing a framework for community action in the field of water policy, The European Parliament and the Council of the European Union, Luxembourg.

Falconer I.R., Humpage A.R., 1996, Tumour promotion by cyanobacterial toxins, Phycologia, 35:74-79.

Flaim G., Pinamonti V., 2000, I cianobatteri nei laghi trentini. [in:] Aspetti sanitari della problematica dei cianobatteri nelle acque superficiali italiane, Eds. Funari, E., Rapporti ISTISAN 00/30, Istituto Superiore di Sanità, Rome, pp. 111-116, (in Italian).

Furey A., Crowley J., Hamilton B., 2005, Strategies to avoid the misidentification of anatoxin-a using mass spectrometry in the forensic investigation of acute neurotoxic poisoning, J. Chromatogr. A, 1082:91-97.

Garibaldi L., Brizzio M.C., Galanti G., Varallo A., Mosello R., 1997, Idrochimica e fitoplancton del Lago d'Idro, Documenta Istituto Italiano di Idrobiologia, 61:153-172 (in Italian).

Hiller S., Krock B., Cembella A., Luckas B., 2007, Rapid detection of cyanobacterial toxins in precursor ion mode by liquid chromatography tandem mass spectrometry. J. Mass. Spectrom.,42, 9:1238-1250.

Humpage A., 2008, Toxin types, toxicokinetics and toxicodynamics. [in:] Cyanobacterial harmful algal blooms: state of the science and research needs. Eds. Hudnell H.K., Springer, New York, pp. 383-415.

Italian Ministry of Health, 1998, Circolare Ministero Sanità 31/7/1998 IX.400.4/13.1/3/1447 (in Italian).

IRSA, 1984, Catasto dei laghi italiani - Vol. 1 - Italia Settentrionale. Quaderni IRSA, Roma (in Italian).

Kosol S., Schmidt J., Kurmayer R., 2009, Variation in peptide net production and growth among strains of the toxic cyanobacterium Planktothrix spp, Eur. J. Phycol., 44, 1:49-62.

Legendre P. and Legendre L., 1998, Numerical ecology, 2nd English edition, Elsevier Science BV, Amsterdam.

Legnani E., Copetti D., Oggioni A., Tartari G., Palumbo M.T., Morabito G., 2005, Planktothrix rubescens seasonal dynamics and vertical distribution in Lake Pusiano (North Italy), J. Limnol., 64:61-73.

Manganelli M., Scardala S., Stefanelli M., Vichi S., Mattei D., Bogialli S., Ceccarelli P., Corradetti E., Petrucci I., Gemma S., Testai E., Funari E., 2010, Health risk evaluation associated to Planktothrix rubescens: An integrated approach to design tailored monitoring programs for buman exposure to cyanotoxins, Water Res., 
44, 1297-1306.

Mazur H., Lewandowskaagata J., Blaszczyka A., Kot A., Plinski M., 2003, Cyanobacterial toxins in fresh and brackish waters of Pomorskie Province (Northern Poland), Oceanol. Hydrobiol. St., 32, 1, 15-26.

Meriluoto J., Codd G.A., 2005, TOXIC, Cyanobacterial Monitoring and Cyanotoxin Analysis, 65, ISBN, 951-765-259-3.

Messineo V., Mattei D., Melchiorre S., Salvatore G., Bogialli S., Salzano R., Mazza R., Capelli G., Bruno M., 2006, Microcystin diversity in a Planktothrix rubescens population from Lake Albano (Central Italy), Toxicon 48, 2:160-174.

Messineo V., Melchiorre S., Di Corcia A., Gallo P., Bruno M., 2009, Seasonal Succession of Cylindrospermopsis raciborskii and Aphanizomenon ovalisporum Blooms with Cylindrospermopsin Occurrence in the Volcanic Lake Albano, Central Italy, Environ. Toxicol., 25, 1:18-27.

Mosello R., Ambrosetti W., Arisci S., Bettinetti R., Buzzi F., Calderoni A., et al, 2010, Evoluzione recente della qualità delle acque dei laghi profondi sudalpini (Maggiore, Lugano, Como, Iseo e Garda) in risposta alle pressioni antropiche e alle variazioni climatiche, Biologia Ambientale, 24, (1), 167-177 (in Italian).

Mosello R., Giussani G., 1997, Evoluzione recente della qualità delle acque dei laghi profondi sudalpini. Documenta Istituto Italiano di Idrobiologia 61:1-228 (in Italian).

Namikoshi M., Murakami T., Watanabe M.F., Oda T., 2003, Simultaneous production of homoanatoxin- $a$, anatoxin- $a$, and a new non-toxic 4-bydroxyhomoanatoxin-a by the cyanobacterium Raphidiopsis mediterranea Skuja, Toxicon, 42:533 -538.

Naselli-Flores L., Barone R., 2007, Pluriannual morphological variability of phytoplankton in a highly productive Mediterranean reservoir (Lake Arancio, Southwestern Sicily), Hydrobiologia, 578:87-95.

Naselli-Flores L., Barone R., Chorus I., Kurmayer R., 2007, Toxic cyanobacterial blooms in reservoirs under a semiarid Mediterranean climate: The magnification of a problem, Environ. Toxicol., 22:399404.

Oksanen I., Jokela J., Fewer D.P., Wahlsten M., Rikkinen J., Sivonen K., 2004, Discovery of rare and bighly toxic microcystins from lichenassociated cyanobacterium Nostoc sp. strain IO-102-I, Appl. Environ. Microbiol., 70, 10:5756-5763.

R Development Core Team (2011). R: A language and environment for statistical computing. $\mathrm{R}$ Foundation for Statistical Computing, Vienna, Austria. ISBN 3-900051-07-0, URL http://www.R-project.org/.

Rohrlack T., Christoffersen K., Hansen P.E., Zhang W., Czarnecki O., Henning M., Fastner J., Erhard M., Neilan B.A., Kaebernick M., 2003, Isolation, characterization, and quantitative analysis of microviridin J, a new Microcystis metabolite toxic to Daphnia, J. Chem. Ecol., 29, 8:1757-1770.

Rohrlack T., Edvardsen B., Skulberg R., Halstvedt C.B., Utkilen H.C., Ptacnik R., and Skulberg O.M., 2008, Oligopeptide chemotypes of the toxic freshwater cyanobacterium Planktothrix can form subpopulations with dissimilar ecological traits, Limnol. Oceanogr. 53, 4:1279-1293.

Salmaso N., 2005, Fioriture di cianobatteri nei laghi profondi dell'Italia settentrionale. [in:] Diffusione delle fioriture algali tossiche nelle acque italiane: gestione del rischio ed evidenze epidemiologiche, Eds., Mattei, D., Melchiorre, S., Messineo, V., Bruno, M., Rapporti ISTISAN 05/29, Istituto Superiore di Sanità, Rome, pp. 3048 (in Italian).

Salmaso N, 2010, Long-term phytoplankton community changes in a deep subalpine lake: responses to nutrient availability and climatic fluctuations, Freshwater Biol., 55:825-846.

Salmaso N., Carrer M.G., Cordella P., 2005, Comparative analysis of phytoplankton diversity in two connected eutrophic lakes (Laghi di Revine, North-Eastern Italy), Verh. Int. Ver. Theor. Ang. Limnol. 29, 390-394.

Salmaso N., Morabito G., Buzzi F., Garibaldi L., Simona M., Mosello R., 2006, Phytoplankton as an indicator of the water quality of the deep lakes south of the Alps. Hydrobiologia, 563:167-187.

Salmaso N., Morabito G., Garibaldi L., Mosello R., 2007, Trophic development of the deep lakes south of the Alps: a comparative analysis, Fund. Appl. Limnol., 170:177-196

Salmaso N., Morabito G., Mosello R., Garibaldi L., Simona M., Buzzi F., Ruggiu D., 2003, A synoptic study of phytoplankton in the deep lakes south of the Alps (lakes Garda, Iseo, Como, Lugano and Maggiore), J. Limnol., 62:207-227.

Salmaso N., Mosello R., 2010, Limnological research in the deep southern subalpine lakes: synthesis, directions and perspectives, Advances in Oceanography and Limnology, 1, (1) 23 - 49.

Sechi N., Lugliè A., 1992, Limnological studies on man-made lakes in Sardinia (Italy), Memorie Istituto Italiano di Idrobiologia, 50:365-381.

Sivonen K., Jones G., 1999, Cyanobacterial toxins. [in:] Toxic Cyanobacteria in Water: a Guide to Their Public Health Consequences, Monitoring and Management. Eds. Chorus I., Bartram J., E \& FN Spon, London, pp. 41-111.

Spoof L., Vesterkvist P., Lindholm T., Meriluoto J., 2003, Screening for cyanobacterial bepatotoxins, microcystins and nodularin in environmental water samples by reversed-phase liquid chromatographyelectrospray ionisation mass spectrometry, J. Chromatogr. A, 1020:105-119.

van Apeldoorn M.E., van Egmond H.P., Speijers G.J.A., Bakker G.J.I., 2007, Toxins of cyanobacteria, Mol. Nutr. Food Res., 51:7-60.

Viaggiù E., Melchiorre S., Volpi F., Di Corcia A., 2004, Anatoxina toxin in the cyanobacterium Planktothrix rubescens from a fishing pond in Northern Italy, Environ. Toxicol., 19:191 -197.

Welker M., Fastner J., Erhard M., von Dohren H., 2002, Application of MALDI-TOF MS analysis in cyanotoxin research, Inc. Environ. Toxicol., 17:367-374.

Welker M., von Dohren H., 2006, Cyanobacterial peptides - Nature's own combinatorial biosynthesis, FEMS Microbiol. Rev., 30, 4:530563.

Whitton B.A., Potts M., 2000, The ecology of yyanobacteria. Their diversity in time and space, Kluwer Academic Publisher, Dordrecht, The Netherlands.

WHO, 1998, Guidelines for Drinking Water Quality, 2nd ed. Addendum to vol. 2. Health Criteria and Other Supporting Information, World Health Organization, Geneva.

Wolf H.U., Frank C., 2002, Toxicity assessment of cyanobacterial toxins mixtures, Environ. Toxicol., 17:395-399.

Zurawell R.W., Chen H.R., Burke J.M., Prepas E.E., 2005, Hepatotoxic cyanobacteria: A review of the biological importance of microcystins in freshwater environments, J. Toxicol. Env. Heal. B, 8, 1:1-37. 